\title{
Characterization of oncogene suppressor marker expression in patients with submucosal gastric carcinoma
}

\author{
ROBERSON A. MORON ${ }^{1}$, CARLOS EDUARDO JACOB ${ }^{1}$, CLAUDIO JOSÉ CALDAS BRESCIANI ${ }^{1}$, \\ KLEBER SIMÕES $^{2}$, VENÂNCIO AVANCINI FERREIRA ALVES ${ }^{2}$, KYOSHI IRYA ${ }^{2}$, JOAQUIM GAMA-RODRIGUES ${ }^{1}$, \\ IVAN CECCONELLO $^{1}$, ADHEMAR LONGATTO-FILHO ${ }^{2-4}$ and BRUNO ZILBERSTEIN ${ }^{1}$
}

\begin{abstract}
Departments of ${ }^{1}$ Gastroenterology and ${ }^{2}$ Pathology, and ${ }^{3}$ Laboratory of Medical Investigation (LIM) 14, Department of Pathology, University of São Paulo School of Medicine, São Paulo, SP 14784-400, Brazil;

${ }^{4}$ Life and Health Sciences Research Institute (ICVS), School of Health Sciences, University of Minho, 4710-057 Braga; ICVS/3B's-PT Government Associate Laboratory, Braga/Guimarães, Portugal
\end{abstract}

Received October 14, 2017; Accepted December 6, 2017

DOI: $10.3892 / \mathrm{mco} .2017 .1545$

\begin{abstract}
The aim of the present study was to determine the clinical significance of $\mathrm{p} 53$ and $\mathrm{p} 21^{\text {ras }} \mathrm{p} 21^{\text {wafl }}, \mathrm{p} 27^{\mathrm{kipl}}$ and $\mathrm{p} 16^{\text {ink4a }}$ expression in cases of early gastric cancer. A total of 81 patients who had undergone gastrectomy with D2 lymphadenectomy between 1971 and 2004 were retrospectively investigated. The immunohistochemical expression of $\mathrm{p} 21^{\text {ras }}, \mathrm{p} 53$, $\mathrm{p} 21^{\text {waf1/cip1 }}$, p2 $7^{\mathrm{kipl}}$ and $\mathrm{p} 16^{\mathrm{ink4a}}$ in the tissues was evaluated. In normal, metaplastic and tumoral mucosa, p53 was positive in 53, 87.3, and $87.1 \%$ of the cases, respectively. In the same tissues, $22^{\text {ras }}$ was positive in $85.3,86$ and $96.8 \%$, respectively. Positivity for $\mathrm{p} 16^{\mathrm{ink4a}}$ was detected in $46.3,91.1$ and $86 \%$ of the cases, respectively, whereas $\mathrm{p} 27^{\mathrm{kip} 1}$ was positive in $60,94.7$ and $95.3 \%$, and $\mathrm{p} 21^{\text {wafl/cipl }}$ was positive in $32.4,72.7$ and $71.4 \%$ of the cases, respectively. All the tumors were positive for p53. Tumors with lymph node invasion presented with overexpression (+4) of p53 in $47 \%$ of the cases vs. $17 \%$ of patients who did not have lymph node involvement. Therefore, higher expression of p53, p2 ras and $\mathrm{p} 21^{\text {wafl/cipl }}$ in the tumor exhibited a statistically significant association with lymph node involvement.
\end{abstract}

\section{Introduction}

The incidence and mortality rates of gastric cancer are high, mainly in Western countries, with an estimated 989,600 new gastric cancer cases and 738,000 deaths in 2008, accounting for $8 \%$ of the total cancer cases and $10 \%$ of total cancer-related deaths (1). Asia, Eastern Europe and South America are the principal regions of gastric cancer occurrence, which may be associated with dietary variables and the high prevalence

Correspondence to: Dr Adhemar Longatto-Filho, Laboratory of Medical Investigation (LIM) 14, Department of Pathology, University of São Paulo School of Medicine, 455 Dr Arnaldo Avenue, Room 1147, São Paulo, SP 14784-400, Brazil

E-mail: longatto16@hotmail.com

Key words: gastric cancer, p21 $1^{\text {ras }}, \mathrm{p} 53, \mathrm{p} 21^{\text {waf1/cip1 }}, \mathrm{p} 27^{\mathrm{kip} 1}, \mathrm{p} 16^{\text {ink4a }}$ of Helicobacter pylori (H. pylori) infection (2). However, the gastric carcinoma rates worldwide have decreased markedly (3).

The biology of gastric cancer is associated with the activity of several molecular markers, which are correlated with the risk of lymph node invasion and metastasis; among these markers, $\mathrm{p} 21^{\text {ras }}, \mathrm{p} 53$, $\mathrm{p} 21^{\text {waf1/cip1 }}, \mathrm{p} 27^{\text {kipl }}$ and $\mathrm{p} 16^{\text {ink4a }}$ currently appear to be inherently correlated with gastric cancer behavior (4-8). These markers are differentially expressed, depending on the gastric carcinoma type (9). Well-documented series of tumors with specific immunohistochemical antibodies reported an association between protein expression and clinical outcome (10). Patients with gastric cancer merely invading the mucosal space have a very low incidence of lymph node metastasis, whereas up to $20 \%$ of cases with submucosal invasion had nodal metastasis, requiring lymphadenectomy for complete disease removal (11). As the majority of reports have focused on invasive gastric cancer, the aim of the present study was to investigate a series of early gastric cancers and examine the expression of the p53, p16 ${ }^{\text {ink4a }}, \mathrm{p} 21^{\text {waf1/cipl }}, \mathrm{p} 21^{\text {ras }}$ and $\mathrm{p} 27^{\text {kipl/cipl }}$ proteins in normal, metaplastic and mucosal tumor tissues, and determine the positive and negative correlations with the risk of lymph node metastasis in early gastric cancer patients with submucosal invasion submitted to gastrectomy with D2 lymphadenectomy.

\section{Patients and methods}

Patients. Cases were retrospectively assessed from the files of the Gastric Cancer Database of Hospital das Clínicas of the University of São Paulo School of Medicine (São Paulo, Brazil), between 1971 and 2004. Records from 1,989 patients with gastric cancer were selected. The inclusion criteria were as follows: Patients with primary gastric adenocarcinoma with submucosal invasion who had been submitted to gastrectomy with D2 lymphadenectomy, with at least 15 lymph nodes isolated from the surgical specimen. Patients with previous gastric surgery and gastric stump cancer were excluded. From the 120 patients with submucosal early gastric cancer (EGC), 81 patients fulfilled the inclusion criteria for the present study. Representative areas of tumoral, normal and metaplastic mucosa were selected from new paraffin sections stained with 
hematoxylin and eosin. The Manual Tissue Microarray kit (Beecher ${ }^{\circledR}$, Sun Prairie, WI, USA) was used for removing the samples from the previously selected areas of the donor blocks and create new paraffin blocks of tissue microarrays (TMA).

The gastric carcinomas were classified according to the guidelines of the Japanese Gastric Cancer Association and Union for International Cancer Control (UICC, 1997) and histologically classified according to the Lauren classification (12).

Immunohistochemical reactions. The TMA paraffin blocks were submitted to immunohistochemical examination for the following markers: p2 $1^{\text {ras }}$ (monoclonal mouse antibody; clone NCC-RAS-001, DakoCytomation M0637, Carpinteria, CA, USA), p21 waf1/cip1 (monoclonal mouse antibody; clone SX118, DakoCytomation M7202, Glostrup, Denmark), p27 $7^{\text {kipl }}$ (monoclonal mouse antibody; clone SX53G8 DakoCytomation M7203), p16 ink4a (monoclonal mouse antibody; clone E6H4 DakoCytomation K5334), and p53 (monoclonal mouse antibody; clone DO-7 DakoCytomation, M7001). For positive reaction observation, $60 \mathrm{mg} \%$ 3,3'-diaminobenzidine tetrahydrochloride (D-5637, Sigma-Aldrich; Merck KGaA, USA), 1 ml dimethylsulfoxide, $1 \mathrm{ml} \mathrm{H}_{2} \mathrm{O}_{2} 6 \%$ and $100 \mathrm{ml}$ phosphate-buffered saline were incubated for $5 \mathrm{~min}$ at $37^{\circ} \mathrm{C}$ in the dark. The specific details of the immunohistochemical reactions are presented in Table I. Positive controls for the anti-p21 ${ }^{\text {ras }}$, anti-p21 ${ }^{\text {waf1/cipl }}$ and anti-p27 $7^{\text {kipl }}$ antibodies were normal palatine tonsyl. For the anti-p53 antibody, the positive control was pulmonary adenocarcinoma. High-grade cervical intraepithelial neoplasia was used as control for anti-p16 $6^{\text {ink4a }}$. Nuclear brown staining was considered as a positive reaction for $\mathrm{p} 53$, $\mathrm{p} 21^{\text {waf1/cip1 }}$ and $\mathrm{p} 27^{\mathrm{kip} 1}$; for $\mathrm{p} 21^{\mathrm{ras}}$, cytoplasmic staining alone was considered as a positive reaction; and for $\mathrm{p} 16^{\mathrm{ink4a}}$, cytoplasmic or nuclear staining was accepted as a positive reaction. The negative control was obtained without the primary antibody incubation stage. The positive immunoreaction quantification was as follows: The samples were quantified in 5 categories: 0 , no cells stained; $1+, \leq 10 \%$ positive cells; $2+$, $11-25 \%$ positive cells; $3+, 26-50 \%$ positive cells; and $4+,>51 \%$ positive cells. The significance of each category was correlated with the pathological variables, avoiding establishing an arbitrary cut-off point. The association analysis between the clinical data and marker positivity was performed using the Chi-squared test. The level of significance was set at $5 \%(\alpha=0.05)$.

Positive controls for the anti-p2 $1^{\text {ras }}$, anti-p2 $1^{\text {wafl/cip1 }}$ and anti-p2 $7^{\mathrm{kip} 1}$ antibodies, were normal amygdale. For the anti-p53 antibody, the positive control was pulmonary adenocarcinoma. High-grade cervical intraepithelial neoplasia was used as control for anti-p16 ${ }^{\text {ink4a }}$.

Nuclear brown staining was considered as a positive reaction for $\mathrm{p} 53, \mathrm{p} 21^{\text {waf } 1 / \mathrm{cip} 1}$ and $\mathrm{p} 27^{\mathrm{kip} 1}$; for $\mathrm{p} 21^{\text {ras }}$, cytoplasmic staining alone was considered as a positive reaction; and for p16 ${ }^{\text {ink4a }}$, cytoplasmic or nuclear staining was accepted as a positive reaction. The negative control was obtained without the primary antibody incubation stage.

Positive immunoreaction quantification. The samples were quantified in five categories: 0 , no cells stained; $1+, \leq 10 \%$ positive cells; $2+, 11-25 \%$ positive cells; $3+, 26-50 \%$ positive cells; and $4+,>51 \%$ positive cells. The significance of each category was correlated with the pathological variables, avoiding establishing an arbitrary cut-off point. The association analysis between the clinical data and marker positivity was performed using the Chi-squared test. The level of significance was set at $5 \%(\alpha=0.05)$.

\section{Results}

Patient characteristics. A total of 81 complete cases were obtained, including tumoral, normal and metaplastic mucosa. There was lymph node invasion in 11 patients (13.6\%). It was not possible to recover the lymph node samples with cancer invasion from the paraffin blocks in 8 cases. The epidemiological and clinical characteristics of the patients are listed in Table II. There were no significant differences between the tumor markers and patient sex (Pearson's Chi-squared test $=2.06$ and $\mathrm{P}=0.55)$. There was no significant association between recurrence and expression of the markers (Pearson's Chi-squared test $=0.76$ and $\mathrm{P}=0.99$ ). The intestinal type was the most common according to the Lauren classification (45 patients, 55.5\%). The diffuse type was observed in $25(30.9 \%)$ patients and the mixed type in $11(13.5 \%)$ patients.

Immunohistochemical reactions. All the immunohistochemical reactions are summarized in Table III. Intestinal type tumors did not express p $21^{\text {wafl }}$ in $29.4 \%$ of the cases. In $67.6 \%$ of the samples, an intermediate positivity $(<25 \%$ of the cells stained) was observed. In only $2.9 \%$ of the cases there was overexpression ( $>25 \%$ of positive cells). Among the diffuse type tumors, there was no expression of $\mathrm{p} 21^{\text {waf } 1 / \mathrm{cip}}$ in $40 \%$ of the cases; intermediate positivity was observed in $45 \%$ and overexpression in $15 \%$ of the cases. Mixed tumors were all positive for $\mathrm{p} 21^{\text {waf1/cip1 }}$ staining; however, $77.8 \%$ exhibited intermediate positivity and $22.2 \%$ exhibited overexpression. (Pearson's Chi-squared test $=16.6$ and $\mathrm{P}=0.034$ ).

Positive reaction for $\mathrm{p} 21^{\mathrm{ras}}$ was observed in the normal mucosa in $81.1 \%$ of the Lauren intestinal type tumors, followed by $86.4 \%$ of the diffuse type and $100 \%$ of the mixed type. A statistically significant difference was observed among the three histological types (Pearson's Chi-squared test $=9.54$ and $\mathrm{P}=0.048$ ). $\mathrm{p} 27^{\mathrm{kip} 1}$ was positive in all cases with diffuse and mixed tumor types. A total of $8.8 \%$ of the intestinal type patients did not exhibit p27 ${ }^{\mathrm{kip} 1}$ expression. Higher immunohistochemical expression of $\mathrm{p} 27^{\mathrm{kip} 1}$ in the tumor was noted in $66.6,50$ and $33.3 \%$ of the diffuse, intestinal and mixed type tumors, respectively. Statistically significant differences were observed among the three histological types (Pearson's Chi-squared test $=16.29$ and $\mathrm{P}=0.038)$. A total of $34(42 \%)$ patients exhibited invasion limited to the superficial part of the submucosal layer (Sm1) and $47(58 \%)$ had invasion to a depth of $>0.5 \mathrm{~mm}(\mathrm{Sm} 2)$. Among the markers, there was a higher positivity only for $\mathrm{p} 27^{\mathrm{kip} 1}$ in the normal mucosa adjacent to Sm1 tumors (Pearson's Chi-squared test $=12.81$ and $\mathrm{P}=0.012$ ).

Perineural invasion occurred in $5(6.17 \%)$ cases. A greater overexpression of p16 ${ }^{\text {ink4a }}$ was observed in normal mucosa in cases with perineural invasion (Pearson's Chi-squared test $=13.42$ and $\mathrm{P}=0.009)$. Vascular invasion was observed in $4(4.9 \%)$ cases. There was a statistically significant correlation between positivity for p16 $6^{\text {ink4a }}$ in normal mucosa and vascular invasion (Pearson's Chi-squared test $=33.42$ and $\mathrm{P}<0,001$ ).

Lymphovascular invasion was observed in 16 cases (19.7\%). A total of $19(23.4 \%)$ patients exhibited lymph node metastasis 
Table I. Summary of the immunohistochemical procedures utilized in the study.

\begin{tabular}{|c|c|c|c|c|}
\hline Antibody & Clone & Dilution & Antigen retrieval & Source \\
\hline $\mathrm{p} 21^{\mathrm{ras}}$ & NCC-RAS-001 & $1: 100$ & $\begin{array}{l}\text { Pressure cooker: Citric acid } \\
10 \mathrm{mM}, \mathrm{pH} 6.0,3^{\prime} \text { and } 30^{\prime}\end{array}$ & $\begin{array}{l}\text { DakoCytomation M0637, } \\
\text { Carpinteria, CA, USA }\end{array}$ \\
\hline $\mathrm{p} 21^{\text {waf1/cip1 }}$ & SX118 & $1: 100$ & $\begin{array}{l}\text { Pressure cooker: Tris-EDTA } \\
1 \mathrm{mM}, \mathrm{pH} 8.0,2^{\prime} \text { and } 30^{\prime}\end{array}$ & $\begin{array}{l}\text { DakoCytomation M7202, } \\
\text { Glostrup, Denmark }\end{array}$ \\
\hline $\mathrm{p} 27^{\mathrm{kip} 1}$ & SX53G8 & $1: 400$ & 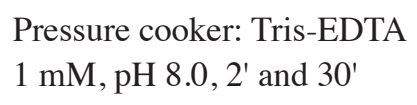 & $\begin{array}{l}\text { DakoCytomation M7203, } \\
\text { Glostrup, Denmark }\end{array}$ \\
\hline $\mathrm{p} 16^{\mathrm{ink} 4 \mathrm{a}}$ & E6H4 & $1: 400$ & $\begin{array}{l}\text { Pressure cooker: Citric acid } \\
10 \mathrm{mM}, \mathrm{pH} 6.0,3^{\prime} \text { and } 30^{\prime}\end{array}$ & $\begin{array}{l}\text { DakoCytomation K5334, } \\
\text { Glostrup, Denmark }\end{array}$ \\
\hline p53 & DO-7 & $1: 200$ & $\begin{array}{l}\text { Pressure cooker: Citric acid } \\
10 \mathrm{mM}, \mathrm{pH} 6.0,3^{\prime} \text { and } 30^{\prime}\end{array}$ & $\begin{array}{l}\text { DakoCytomation, M7001, } \\
\text { Glostrup, Denmark }\end{array}$ \\
\hline
\end{tabular}

EDTA, ethylenediaminetetraacetic acid.

Table II. Clinical characteristics of patients with early gastric carcinoma $(n=81)$.

\begin{tabular}{lc}
\hline Characteristics & No. $(\%)$ \\
\hline Sex & \\
Female & $31(38.3)$ \\
Male & $50(61.7)$ \\
Ethnic groups & \\
Caucasian & $59(72.2)$ \\
Asian & $7(8.6)$ \\
Afro-Brazilian & $14(17.3)$ \\
Others & $1(1.2)$ \\
Mean age, years \pm SD & $61.5 \pm 12.5$ \\
Median age, years \pm SD & $62 \pm 15.8$ \\
Familial history of gastric cancer & $12(14.8)$ \\
Main symptom & \\
Dyspepsia & $58(71.6)$ \\
Asymptomatic & $18(22.2)$ \\
Upper digestive bleeding & $5(6.2)$ \\
Hospital mortality (<30 days) & $5(6.2)$ \\
Brain stroke & $1(1.2)$ \\
Sepsis & $2(2.5)$ \\
Respiratory complications & $2(2.5)$ \\
Follow-up mortality $>30$ days) & $2(2.5)$ \\
Pleural metastasis & $1(1.25)$ \\
Pulmonary metastasis & $1(1.25)$ \\
Histological type (Lauren) & \\
Intestinal & \\
Diffuse & $45(55.5)$ \\
Mixed & $25(30.8)$ \\
Mean number of removed lymph nodes & $11(13.5)$ \\
\hline & \\
Mean follow-up time, months & \\
\hline
\end{tabular}

$\mathrm{SD}$, standard deviation. from adenocarcinoma, of whom 4 (21\%) exhibited Sm2 submucosal invasion and $15(78.9 \%) \mathrm{Sm} 1$ type invasion. According to the Lauren classification, 10 (52.6\%) were intestinal, 7 (36.8\%) were diffuse and 2 (10.5\%) were mixed type.

There was a correlation between the higher expression of p53 in the tumor and the presence of lymph node involvement (Pearson's Chi-squared test $=8.18$ and $\mathrm{P}=0.042$ ). Patients with lymph node involvement also exhibited a higher expression of p21 $1^{\text {waf } 1 / \text { cip } 1}$ (Pearson's Chi-squared test $=15.86$ and $\mathrm{P}=0.003$ ). Lymph node invasion was correlated with positive expression of p21 ${ }^{\text {ras }}$ (Pearson's Chi-squared test $=9.533$ and $\mathrm{P}=0.023$ ), but not of p16 ink4a $($ Pearson's Chi-squared test $=1.27$ and $\mathrm{P}=0.86$ ) or p27 ${ }^{\text {kip1 }}$ (Pearson's Chi-squared test $=2.55$ and $\mathrm{P}=0.63$ ). All the markers were significantly enhanced when the tumor was compared with normal mucosa. Comparison of normal and metaplastic mucosa revealed an increased expression of p53, $\mathrm{p} 21^{\text {waf } 1 / \mathrm{cip} 1}$ and $\mathrm{p} 27^{\mathrm{kip} 1}$, but not $\mathrm{p} 16^{\text {Ink4a }}$ and $\mathrm{p} 21^{\text {ras }}$. The comparison of metaplastic and tumoral mucosa revealed increased expression of $\mathrm{p} 21^{\mathrm{ras}}$ in cancer cells.

\section{Discussion}

The results herein observed endorse, in part, the data available in the literature. Despite the excellent prognosis of early gastric adenocarcinoma when there is no lymph node metastasis, the majority of the markers correlated with cancer aggressiveness are associated with early stages of carcinoma invasion. Studies using immunohistochemical markers have the limitation inherent to the semi-quantification of the positive reactions (5-7).

There is robust experimental evidence that genetic alterations and risk factors differ according to the histological type (13). Our results revealed significant differences between neoplastic and non-neoplastic protein expression, which corroborate, in part, the evidence observed in experimental settings. Normal mucosa exhibited p $21^{\text {ras }}$ positivity in $81.1 \%$ of the patients with intestinal type carcinoma, $86.4 \%$ with diffuse type, and $100 \%$ with mixed type, as previously reported (14). The prognostic value of $\mathrm{p} 21^{\text {ras }}$ in intestinal type carcinomas remains disputable (15). 


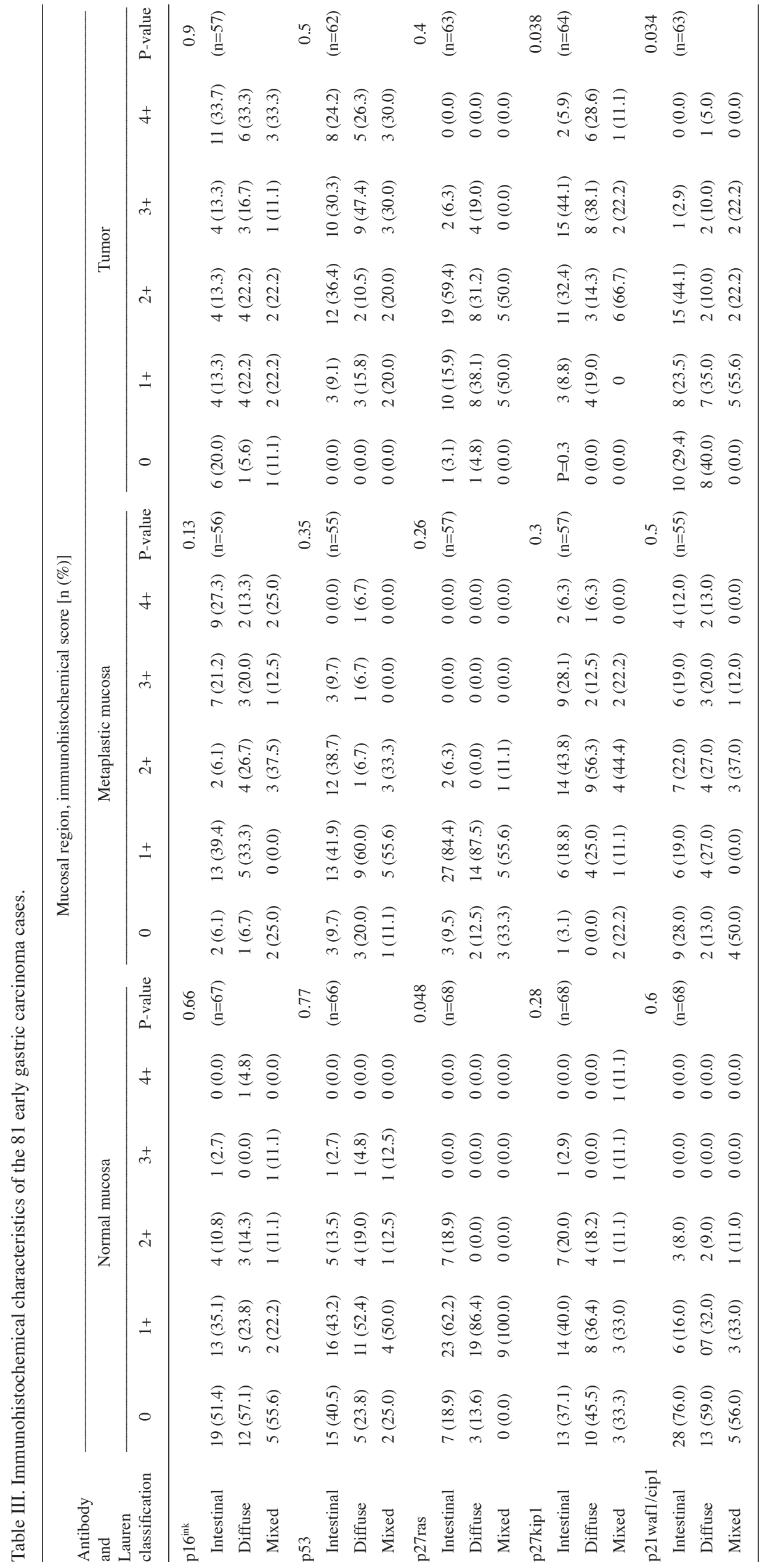


Hyperexpression of $\mathrm{p} 21^{\text {waf1/cip } 1}$ was observed in diffuse and mixed type tumors, and the diffuse type included more cases with loss of expression of $\mathrm{p} 21^{\text {waf } 1 / \text { cip } 1}$. These results were quite different from other studies that did not observe differences in p $21^{\text {waf } 1 / \text { cip } 1}$ expression among the histological types of gastric carcinoma (16-18). The incidence of lymph node metastasis is considered to be relatively higher in tumors with a superficially spreading growth pattern compared with the vertically infiltrating type, and the expression of $\mathrm{p} 21^{\text {waf1/cip1 }}$ was lower in the superficial spreading tumors (19).

However, we observed a strong positivity for $\mathrm{p} 27^{\mathrm{kip} 1}$ in all tumors and a greater positivity in the diffuse type cases, as previously reported $(4-6,14)$. The statistical analysis revealed greater positivity in the expression of $\mathrm{p} 27^{\mathrm{kip} 1}$ in normal mucosa adjacent to Sm1 tumors. Although there was expression of $\mathrm{p} 27^{\mathrm{kip} 1}$ in normal mucosa of $\mathrm{Sm} 2$ cases, there were fewer positive cells. We observed a progressive increase in the expression of p $27^{\mathrm{kipl}}$ in normal, metaplasic and tumoral mucosa. H. pylori infection was found to induce AKT/PI3K-mediated phosphorylation of p27, leading to cytoplasmic p27 mislocalization in gastric cancer, which is an adverse prognostic feature in gastric cancer. This is important, as p27 has both tumor-suppressive and oncogenic properties related to its subcellular localization. Cytoplasmic mislocalization of $\mathrm{p} 27$ induced by H. pylori may be an important mechanistic link between $H$. pylori infection and gastric carcinogenesis (20).

An association between hyperexpression of $16^{\text {ink4a }}$ in normal mucosa and perineural and vascular invasion was observed. Similar results were not reported in the literature $(8,14)$. However, there was no correlation between increased expression of p16 ${ }^{\text {ink4a }}$ (and p27 $7^{\mathrm{Kipl}}$ ) and lymph node invasion. Lymph node involvement was more frequent in $\mathrm{p} 21^{\text {ras }}$-positive cases $(\mathrm{P}=0.023)$; inversely, cases with negative $\mathrm{p} 21^{\text {ras }}$ expression in the tumoral mucosa, did not exhibit lymph node metastasis. However, this result contradicts the findings of Kim et al (21), who did not identify a significant correlation between $\mathrm{p} 21^{\text {ras }}$ positivity and lymph node metastasis in advanced gastric cancer. p $21^{\text {ras }}$ positivity was not exclusively identified in tumor tissues, but was also described in non-neoplastic and normal tissues (22). The expression of p21 ${ }^{\text {ras }}$ is generally augmented in gastric adenocarcinoma and may be associated with worse prognosis. The correlation between lymph node invasion and hyperexpression of $\mathrm{p} 21^{\text {ras }}$ may be useful for selecting therapeutic alternatives for patients with $\mathrm{p} 21^{\text {ras }}$-negative tumors $(23,24)$.

A significant increase in the incidence of lymph node invasion was observed in cases with marked immunohistochemical positivity for $\mathrm{p} 53$ in tumor samples $(\mathrm{P}=0.042)$, as previously documented $(4,5)$.

Lymph node involvement was also statistically related to tumor cell positivity for $\mathrm{p} 21^{\text {waf } 1}$. None of the gastric carcinomas with negative immunoreaction for $\mathrm{p} 21^{\text {waf } 1}$ exhibited lymph node metastasis, and there was a higher frequency of lymph node involvement in cases with greater positivity for $\mathrm{p} 21^{\text {waf1 }}$, as previously documented $(17,25)$. It was observed that $65.4 \%$ of the cases were positive for $\mathrm{p} 21^{\text {waf } 1}$, and a higher incidence of lymph node involvement was also found in patients with increased proliferative activity and loss of expression of $\mathrm{p} 21^{\text {waf1 }}$ in tumor tissue (26). The loss of $\mathrm{p} 21^{\text {waf1 }}$ expression and the relapse and mortality rates of gastric cancer indicate that the expression of $\mathrm{p} 21^{\text {wafl }}$ is of prognostic value (25-27). Despite strong evidence supporting the role of $\mathrm{p} 21^{\text {waf } 1}$ as a prognostic marker, this finding remains debatable (28).

There was no correlation observed between the expression of $\mathrm{p} 27^{\mathrm{kip} 1}$ in the tumor and the presence of lymph node involvement in advanced cancer cases (29). We did not identify a statistical correlation between the presence of lymph node involvement and the immunohistochemical expression of p16 ${ }^{\text {ink4a }}$. This is a conflicting result compared with previous reports $(30,31)$. Although the expression of p16 ${ }^{\text {ink4a }}$ is altered in gastric tumors, this alteration is considered to be secondary to p53 mutations (5). In normal mucosa, the expression of p16 ${ }^{\text {ink4a }}$ has been reported to be low (32). In gastric tumors, the p16 ${ }^{\text {ink4a }}$ expression is expected to be increased in intestinal and diffuse type tumors, but no significant difference in patients' life expectancy was reported (32).

The p16 protein was expressed in $>95 \%$ of the normal gastric mucosa, $92 \%$ of dysplastic gastric mucosa and in almost $45 \%$ of gastric carcinoma samples (32). In addition, the expression of p16 in carcinoma metastatic to the lymph nodes was significantly reduced compared with the expression in the primary tumor (32).

A gradual decrease of $\mathrm{p} 21^{\mathrm{waf} 1}, \mathrm{p} 27^{\mathrm{kip} 1}$ and $\mathrm{p} 16^{\mathrm{ink4a}}$ immunoreactions was expected from the normal to metaplastic and tumor tissue; however, increased rates of immune positive reactions for all markers were observed. It was hypothesized that, in the early stages of cancer development, these mechanisms of cell regulation remain functional and, eventually become overexpressed in an attempt to prevent abnormal cellular proliferation. The progressive increase of the positivity for the protein markers in normal, metaplastic and tumoral mucosa occurred in parallel to the increase of the expression of $\mathrm{p} 21^{\text {ras }}$ (which stimulates cell division), as well as p53 (which reflects the loss of the main pathway of cell maintenance control), the most commonly affected by mutations (33). The increased p53 expression detected by immunohistochemistry is frequently indicative of mutations in the 553 gene (34). This rationale may apply to $\mathrm{p} 21^{\text {ras }}$ as well, since mutations are present in $\sim 15 \%$ of the tumors, and, specifically in gastric cancer, direct mutations of $\mathrm{p} 21^{\mathrm{ras}}$ are less frequent $(35,36)$. Mutations of the p16 gene in gastric cancer, however, appear to be uncommon, and the decrease in the expression of this protein in gastric cancer is considered to be secondary to other, still unknown mechanisms (37). Additionally, mutations of the $\mathrm{p} 27^{\mathrm{kip} 1}$ and $\mathrm{p} 21^{\text {waf1 }}$ genes are also reported to be infrequent (38). The increased expression of these markers in early tumors is hypothesized to be an indirect consequence of an unknown mutation and/or abnormal mechanism of controlling cell division.

In summary, the analysis of the clinical characteristics and the immune expression of p53, p2 $1^{\text {ras }}, \mathrm{p} 27^{\mathrm{kip} 1}, \mathrm{p} 21^{\text {waf1 }}$ and p16 $6^{\text {ink4a }}$ in patients with early gastric adenocarcinoma with submucosal invasion led to the conclusion that there is an important increase in the immunohistochemical expression of $\mathrm{p} 53, \mathrm{p} 21^{\text {ras }}, \mathrm{p} 27^{\mathrm{kip} 1}, \mathrm{p} 21^{\text {waf1/cip1 }}$ and $\mathrm{p} 16^{\mathrm{ink4a}}$ when normal tissue is compared with neoplastic parenchyma. There is also a positive correlation between higher tumor expression of p21 ${ }^{\text {ras }}, \mathrm{p} 53$ and $\mathrm{p} 21^{\text {waf } 1 / \mathrm{cip} 1}$ and the presence of lymph node metastases, which was not observed for $\mathrm{p} 27^{\mathrm{kip} 1}$ and $\mathrm{p} 16^{\text {ink4a }}$. Finally, tumors with $\mathrm{Sm} 1$ invasion exhibited a higher positivity for $\mathrm{p} 21^{\text {waf1/cip1 }}$, whilst overexpression of $\mathrm{p} 16^{\text {ink4a }}$ in the normal mucosa was associated with perineural and vascular invasion. 


\section{References}

1. Torre LA, Bray F, Siegel RL, Ferlay J, Lortet-Tieulent J and Jemal A: Global cancer statistics, 2012. CA Cancer J Clin 65 : 87-108, 2012

2. Wroblewski LE, PeekRM Jr and Wilson KT: Helicobacter pylori and gastric cancer: Factors that modulate disease risk. Clin Microbiol Rev 23: 713-739, 2010.

3. Buckland G,Agudo A,LujánL,JakszynP,Bueno-de-MesquitaHB, Palli D, Boeing H, Carneiro F, Krogh V, Sacerdote C, et al Adherence to a Mediterranean diet and risk of gastric adenocarcinoma within the European Prospective Investigation into Cancer and Nutrition (EPIC) cohort study. Am J Clin Nutr 91: 381-390, 2010

4. Liu XP, Kawauchi S, Oga A, Suehiro Y, Tsushimi K, Tsushimi M and Sasaki K: Combined examination of p27 (Kip1), p21 (Waf1/Cip1) and p53 expression allows precise estimation of prognosis in patients with gastric carcinoma. Histopathology 39 : 603-610, 2001

5. Al-Moundhri MS, Nirmala V, Al-Hadabi I, Al-Mawaly K, Burney I, Al-Nabhani M, Thomas V, Ganguly SS and Grant C: The prognostic significance of p53, p27 kip1, p21 waf1, HER-2/neu and Ki67 proteins expression in gastric cancer: A clinicopathological and immunohistochemical study of $121 \mathrm{Arab}$ patients. J Surg Oncol 91: 243-252, 2005.

6. Gamboa-Dominguez A, Seidl S, Reyes-Gutierrez E, Hermannstädter C, Quintanilla-Martinez L, Busch R, Höfler H, Fend F and Luber B: Prognostic significance of p21WAF1/CIP1, p27Kip1, p53 and E-cadherin expression in gastric cancer. J Clin Pathol 60: 756-761, 2007.

7. Alves MK, Ferrasi AC, Lima VP, Ferreira MV, de Moura Campos Pardini MI and Rabenhorst SH: Inactivation of COX-2, HMLH1 and CDKN2A gene by promoter methylation in gastric cancer: Relationship with histological subtype, tumor location and Helicobacter pylori genotype. Pathobiology 78: 266-276, 2011.

8. Wang P, Mei J, Zhang N, Tao J, Tian H and Fu GH. Helicobacter pylori upregulates the expression of p16 (INK4) in gastric cancer cells. Hepatogastroenterology 58: 846-853, 2011.

9. Begnami MD, Fregnani JH, Brentani H, Torres C, Costa WL Jr, Montagnini A, Nonogaki S and Soares FA: Identification of protein expression signatures in gastric carcinomas using clustering analysis: J Gastroenterol Hepatol 27: 378-384, 2012.

10. Begnami MD, Fukuda E, Fregnani JH, Nonogaki S, Montagnini AL, da Costa WL Jr and Soares FA: Prognostic implications of altered human epidermal growth factor receptors (HERs) in gastric carcinomas: HER2 and HER3 are predictors of poor outcome: J Clin Oncol 29: 3030-3036, 2011.

11. Lim MS, Lee HW, Im H, Kim BS, Lee MY, Jeon JY, Yang DH and Lee BH. Predictable factors for lymph node metastasis in early gastric cancer-analysis of single institutional experience: J Gastrointest Surg 15: 1783-1788, 2011.

12. Lauren P. The two histological main types of gastric carcinoma: Diffuse and so-called intestinal type carcinoma. An attempt at a histo-clinical classification. Acta Pathol Microbiol Scand 64 31-49, 1965

13. Shimada S, Mimata A, Sekine M, Mogushi K, Akiyama Y, Fukamachi H, Jonkers J, Tanaka H, Eishi Y and Yuasa Y: Synergistic tumour suppressor activity of E-cadherin and p53 in a conditional mouse model for metastatic diffuse-type gastric cancer. Gut 61: 344-353, 2012.

14. Mattioli E, Vogiatzi P, Sun A, Abbadessa G, Angeloni G, D'Ugo D, Trani D, Gaughan JP, Vecchio FM, Cevenini G, et al: Immunohistochemical analysis of pRb2/p130, VEGF, EZH2, p53, p16 (INK4A), p27 (KIP1), p21 (WAF1), Ki-67 expression patterns in gastric cancer. J Cell Physiol 210: 183-191, 2007.

15. Kasper HU, Schneider-Stock R, Mellin W and Roessner A: P21 protein expression and ras-oncogene mutations in gastric carcinoma: Correlation with clinical data. Int J Oncol 12: 69-74, 1998.

16. Teh M and Lee YS. An immunohistochemical study of ras oncoprotein expression in gastric carcinoma: Cancer 72: 1846-1848, 1993.

17. Yasui W, Akama Y, Kuniyasu H, Yokozaki H, Semba S, Shimamoto F and Tahara E: Expression of cyclin-dependent kinase inhibitor p21WAF1/CIP1 in non-neoplastic mucosa and neoplasia of the stomach: Relationship with p53 status and proliferative activity. J Pathol 180: 122-128, 1996.

18. Jang SJ, Park YW, Park MH, Lee JD, Lee YY, Jung TJ, Kim IS, Choi IY, Ki M, Choi BY and Ahn MJ: Expression of cell-cycle regulators, cyclin E and p21WAF1/CIP1, potential prognostic markers for gastric cancer. Eur J Surg Oncol 25: 157-163, 1999.
19. Ichinoe M, Mitomi H,Kikuchi S, Tanabe S, AkinoF and Okayasu I Mucosal high apoptotic activity and low p21WAF1/CIP1 expression and submucosal low proliferative activity in superficially spreading early gastric cancers: Comparison with the penetrating growth type. Pathol Int 53: 81-89, 2003

20. Wen S, So Y, Singh K, Slingerland JM, Resnick MB, Zhang S, Ruiz V and Moss SF: Promotion of cytoplasmic mislocalization of p27 by Helicobacter pylori in gastric cancer: Oncogene 31: 1771-1780, 2011.

21. Kim DH, Lee HI, Nam ES, Shin HS, Sohn JH, Park CH, Yoon DS, Song SY and Park YE: Reduced expression of the cell-cycle inhibitor $\mathrm{p} 27 \mathrm{Kip} 1$ is associated with progression and lymph node metastasis of gastric carcinoma. Histopathology 36: 245-251, 2000

22. Chesa PG, Rettig WJ, Melamed MR, Old LJ and Niman HL: Expression of p21ras in normal and malignant human tissues: Lack of association with proliferation and malignancy. Proc Natl Acad Sci USA 84: 3234-3238, 1987.

23. Mita H, Toyota M, Aoki F, Akashi H, Maruyama R, Sasaki Y, Suzuki H, Idogawa M, Kashima L, Yanagihara K, et al: A novel method, digital genome scanning detects KRAS gene amplification in gastric cancers: Involvement of overexpressed wild-type KRAS in downstream signaling and cancer cell growth. BMC Cancer 9: 198, 2009.

24. Kubota E, Kataoka H, Aoyama M, Mizoshita T, Mori Y, Shimura T, Tanaka M, Sasaki M, Takahashi S, Asai K and Joh T: Role of ES cell-expressed Ras (ERas) in tumorigenicity of gastric cancer. Am J Pathol 177: 955-963, 2010

25. Noda H, Maehara Y, Irie K, Kakeji Y, Yonemura $T$ and Sugimachi K: Increased proliferative activity caused by loss of p21 (WAF1/CIP1) expression and its clinical significance in patients with early-stage gastric carcinoma. Cancer 94: 2107-2112, 2002.

26. Ogawa M, Maeda K, Onoda N, Chung YS and Sowa M: Loss of p21WAF1/CIP1 expression correlates with disease progression in gastric carcinoma. Br J Cancer 75: 1617-1620, 1997.

27. Jang SJ, Ahn MJ, Paik SS, Kong G, Keum JS, Park YW and Lee JD: Expression of cyclin dependent kinase inhibitor p21WAF1 alone and in combination with p27KIP1 shows prognostic value in gastric carcinoma. J Korean Med Sci 13: 369-376, 1998.

28. Kaye PV, Radebold K, Isaacs S and Dent DM. Expression of p53 and p21waf1/cip1 in astric carcinoma: Lack of inter-relationship or correlation with prognosis. Eur J Surg Oncol 26: 39-43, 2000.

29. Nitti D, Belluco C, Mammano E, Marchet A, Ambrosi A, Mencarelli R, Segato P and Lise M: Low level of p27 (Kip1) protein expression in gastric adenocarcinoma is associated with disease progression and poor outcome. J Surg Oncol 81: 167-175, 2002.

30. Kishimoto I, Mitomi H, Ohkura Y, Kanazawa H, Fukui N and Watanabe M: Abnormal expression of p16 (INK4a), cyclin D1, cyclin-dependent kinase 4 and retinoblastoma protein in gastric carcinomas. J Surg Oncol 98: 60-66, 2008.

31. Mattioli E, Vogiatzi P, Sun A, Abbadessa G, Angeloni G, D'Ugo D, Trani D, Gaughan JP, Vecchio FM, Cevenini G, et al: Immunohistochemical analysis of pRb2/p130, VEGF, EZH2, p53, p16 (INK4A), p27 (KIP1), p21 (WAF1), Ki-67 expression patterns in gastric cancer. J Cell Physiol 210: 183-191, 2007.

32. He XS, Su Q, Chen ZC, He XT, Long ZF, Ling H and Zhang LR Expression, deletion and mutation of p16 gene in human gastric cancer. World J Gastroenterol 7: 515-521, 2001

33. Fenoglio-Preiser Cm, Wang J, Stemmermann $\mathrm{Gn}$ and Noffsinger A. TP53 and Gastric Carcinoma: A Review. Hum Mutat 21: 258-270,2003.

34. Noda H, Maehara Y, Irie K, Kakeji Y, Yonemura T and Sugimachi K. Growth pattern and expressions of cell cycle regulator proteins p53 and p21waf1/cip1 in early gastric carcinoma. Cancer 92: 1828-1835, 2001.

35. Yasui W, Akama Y, Kuniyasu H, Yokozaki H, Semba S, Shimamoto F and Tahara E: Expression of cyclin-dependent kinase inhibitor p2lWAFI/CIP1 in non-neoplasic mucosa and neoplasia of the stomach: Relationship with p53 status and proliferative activity. J Pathol 180: 122-128, 1996.

36. Czerniak B, Herz F, Gorczyca W and Koss LG: Expression of ras oncogene $\mathrm{p} 21$ protein in early gastric carcinoma and adjacent gastric epithelia. Cancer 164: 1467-1473, 1989.

37. Igaki $H$, Sasaki H, Tachimori $Y$, Kato H, Watanabe H, Kimura T, Harada Y, Sugimura T and Terada M: Mutation frequency of the p16/CDKN2 gene in primary cancers in the upper digestive tract. Cancer Res 55: 3421-3423, 1995.

38. Ohuchi N, Hand PH, Merlo G, Fujita J, Mariani-Costantini R, Thor A, Nose M, Callahan R and Schlom J: Enhanced expression of c-Ha-ras p21 in human stomach adenocarcinomas defined by immunoassays using monoclonal antibodies and in situ hybridization. Cancer Res 47: 1413-1420, 1987. 